Available online at: http://proceeding.rsfpress.com/index.php/ic-smart/index

Proceeding on International Conference of Science Management Art Research Technology

(IC-SMART)

Volume 1 Number 1 (2020): 71-77

\title{
Improving Mathematical Reasoning Ability Through Guided Discovery Methods Assisted By Autograph Software
}

\author{
Ismail Hanif Batubara, Marah Doly Nasution \\ University Of Muhammadiyah Sumatera Utara; \\ E-mail address ismailhanifbatubaraumsu@gmail.com
}

\begin{abstract}
This study aims to compare the improvement of students' mathematical reasoning abilities taught by guided discovery learning methods assisted by autograph with the guided discovery learning method without autograph software. This research is a quasi-experimental study with a population of 122 people. Randomly two classes are selected from the available classes divided into two sample classes. The first experimental class was given treatment by Guided Discovery learning Method assisted by autograph software, while another class was given treatment by guided discovery learning method without autograph software. The instrument used in this study was a test. Then the test results are tested using the t-test with the help of SPSS with the test criteria is reject $\mathrm{HO}$ if the t-table is smaller than t arithmetic. The results showed that the tcount was 2,785 while the t table was 2,000. It means that the students who are taught by the guided discovery learning method assisted by autograph (First experiment) are higher than the students who are taught by the guided discovery learning method without autograph (Second experiment).
\end{abstract}

Keywords: Mathematical Reasoning, Guided Discovery Method, Autograph

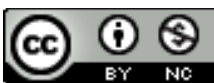

This is an open access article under the CC-BY-NC license

\section{INTRODUCTION}

The reasoning is very important in a person. Without reasoning about the material, someone can't be able to master the material. For an educator, the reasoning is something that cannot be negotiated in terms of the implementation of the Tri Dharma of Higher Education, which states that every educator must carry out teaching. Likewise, with a teacher and prospective teacher, mastery of material and reasoning are very urgent. Regrettably, there are several students who don't use proficient materials of mathematical modeling courses, which are educational materials in schools such as linear, integral programs, and so on.

One of the cases is students can't draw how to make a chart from a function, circles, trigonometry, and others. Some students were doubtful and anxious to solve the problem. To become an educator, we have to able to explain the lesson and making transferred knowledge as good as possible. The disparity among actuality and hope at this time develop into my history to doing this investigation and finding a solution and comparing of reasoning student abilities. 


\section{LITERATURE REVIEW}

Guided Discovery Learning (GDL) is one of the keys to solving the problems. GDL is learning by giving students an obstacle first, and students collecting evidence, adjust the assumes, experimenting, looking for regularities, compiling the specifications, proving whether the allegation is true or not later (Sadiq, 2009, p.12). Therefore this method allows students to build their cognitive aspects through various activities that are designed to produce a convolution depend on student understanding.

ICT backing Autograph and other software is one solution that can attract students' interest in learning. As explained, the Autograph-assisted PBL model is best used when combined with technology (Batubara, IH, 2017, p.99). Found on the complication over, in addition to some of the results previously noticed, the researcher combines guided discovery learning with computer technology (Autograph or others) media.

\section{RESEARCH METHODOLOGY}

This research is quasi-experimental research conducted with guided discovery assisted by Autograph software. This research was conducted at the Faculty of Teacher Training and Education (FKIP) Muhammadiyah University of North Sumatra, Jl Mukhtar Basri No.3 Medan. The population of this research is all class five-semester mathematics study program. The samples of this study were two classes selected from the mathematics education study program FKIP UMSU for the 2019/2020 academic year, which was carried out before and after the COVID 19 pandemic. (2) the stage of testing the learning tools and research instruments, (3) the stage of the experiment, and (4) the stage of the analysis of the research results.

The samples were grouped into two groups or classes, namely: (1) the first group or first class was used as the experimental class 1, which received GDL assisted by Autograph, (2) the second class was used as experimental class 2 , which received learning using the discovery method guided without Autograph software. The design in this study was in the form of a non-equivalent control group (Russeffendi, 1993). The research design is as follows:

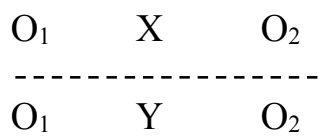

$\mathrm{X}$ is a treatment in the form of Guided Discovery Method assisted by Autograph Software, while $\mathrm{Y}$ is a treatment in the form of Guided Discovery method without Autograph software. Both X and Y were given a pretest $(\mathrm{O} 1)$ and post-test $(\mathrm{O} 2)$ for data analysis. The relationship between the provision of guided discovery method learning with Autograph software and the guided discovery method without Autograph software on students' mathematical reasoning abilities in this study can be seen in the Weiner table (Modification of Saragih. S, 2007, p. 67) below: 
Tabel 1 : Weiner's Model Relationship between Research Variables

\begin{tabular}{|l|l|c|}
\hline $\begin{array}{l}\text { Students } \\
\text { Early } \\
\text { Mathematical } \\
\text { Ability }\end{array}$ & \multicolumn{2}{|l|}{ Mathematical Reasoning (MR) } \\
\cline { 2 - 3 } & $\begin{array}{l}\text { Autograph- } \\
\text { assisted Guided } \\
\text { Discovery Method } \\
\text { (A) }\end{array}$ & $\begin{array}{l}\text { Guided Discovery } \\
\text { Method Without } \\
\text { Autograph (B) }\end{array}$ \\
\hline High (H) & MRHA & MRHB \\
\hline Medium (M) & MRMA & MRMB \\
\hline Low (L) & MRLA & MRLB \\
\hline Whole & MRA & MRB \\
\hline
\end{tabular}

Data Analyzed from students' pretest and posttest. The data obtained from the scores of students 'mathematical reasoning abilities were grouped according to the learning group (Guided Discovery Learning assisted with Autograph and GDL beyond Autograph) and the students' initial mathematics ability group (high, medium, low). Data processing begins by testing the statistical, including the data normality and homogeneity test. All statistical calculations help by SPSS 16. To test the hypothesis of this study (Improved Student Reasoning Ability), the t-test formula was used with the test criteria rejecting $\mathrm{HO}$ if $t_{\text {table }}<t_{\text {Count }}$ and accept $\mathrm{H} 0$ for other conditions with a predetermined significance level.

\section{FINDING AND DISCUSSION}

The results determined by testing: if the significance obtained is $>0.05$, then the sample comes from a normally distributed population, and if the significance is $<0.05$, the sample is not from a normally distributed population.

Tabel 2. The Results of Normality Test Test of Normality

\begin{tabular}{|c|c|c|c|c|c|c|}
\hline & \multicolumn{3}{|c|}{ Kolmogorov-Smirnova } & \multicolumn{3}{|c|}{ Shapiro-Wilk } \\
\hline & Statistic & df & Sig & Statistic & df & Sig \\
\hline EKS_ & .117 & 30 & $.300^{*}$ & .943 & 30 & .106 \\
\hline $2^{\text {EKS_ }}$ & .134 & 30 & .151 & .933 & 30 & .060 \\
\hline
\end{tabular}

From table 2 above. It appears that the sign value. Kolmogorov Smirnov experiment class I was 0.300 , and experiment class II was 0.151 . The second significant value is greater than the significant level value of 0.05 , so the data for the two classes is normal, in other words, the null hypothesis is accepted. Because the data in two groups (experiment I and experiment II) were normally and homogeneity. The homogeneity showed in the table below: 
Tabel 3. Initial Ability Homogeneity Test Results

\begin{tabular}{|r|r|r|r|}
\hline \multicolumn{4}{|c|}{ Test of Homogeneity of Variances } \\
\hline RESULT & & & \\
\hline $\begin{array}{c}\text { Levene } \\
\text { Statistic }\end{array}$ & $\mathrm{df1}$ & $\mathrm{df2}$ & Sig. \\
\hline .074 & 1 & 58 & .657 \\
\hline
\end{tabular}

From the results of the Levene test using the SPSS 22.0 program, it is known that the KAM significance value is 0.657 . This means that the significant value is greater than $\alpha$, namely 0.05 , so that the initial ability test results for experimental class I and experimental class II students are homogeneous. Based on the normality and homogeneity test above, it can be concluded that the data on the students' initial mathematical abilities are normally distributed and homogeneous.

The test was carried out twice, pretest and posttest. The mathematical reasoning ability test consists of 5 items, both pretest and posttest. Then the pretest, posttest, and N-gain data processing were carried out to obtain the lowest score, highest score, average score, and standard deviation (SD). Then look for the results of N-Gain normality and N-Gain homogeneity to continue processing the next data. The results of $\mathrm{N}$-gain normality are shown in the table below:

Tabel 4. Results of the N-Gain Normality Test for Mathematical Reasoning

\begin{tabular}{|c|c|c|c|c|c|c|}
\hline \multicolumn{7}{|c|}{ Tests of Normality } \\
\hline & \multicolumn{3}{|c|}{ Kolmogorov-Smirnov ${ }^{a}$} & \multicolumn{3}{|c|}{ Shapiro-Wilk } \\
\hline & Statistic & df & Sig. & Statistic & df & Sig. \\
\hline${ }_{1}$ EKS & .109 & 30 & $.160^{*}$ & .947 & 30 & .138 \\
\hline $2^{E K S}$ & .159 & 30 & .081 & .949 & 30 & .161 \\
\hline \multicolumn{4}{|c|}{ a. Lilliefors Significance Correction } & & & \\
\hline \multicolumn{5}{|c|}{ *. This is a lower bound of the true significance. } & & \\
\hline
\end{tabular}

From the table above, it is known that the significance value of the experimental class I was 0.160 , while the experimental class II was 0.81 . Because the significance value of experimental class I $(0.160)$ then sig ex $\mathrm{I}>\alpha(0.160>0.05)$ so that the $\mathrm{N}$-gain data for experimental class I is normally distributed, and for experimental class II, the value of sig $>\alpha(0.081>0.05)$, this means that the Ngain data for the experimental class II is also normally distributed. So the N-gain data for experimental class I and experimental class II come from normally distributed data. Thus the $\mathrm{N}$-gain data on the overall reasoning ability can be concluded with a Normal distribution. After going through the normality test stage, the N-gain data must also go through the Homogeneity test stage. In this study, the homogeneity test used the Levene test, which is shown in the table below:

Tabel 5. Homogeneity Test Results N-Gain Reasoning

\begin{tabular}{|r|r|r|r|}
\hline \multicolumn{4}{|c|}{ Test of Homogeneity of Variances } \\
\hline Mathematic Reasoning & & \\
\hline Levene Statistic & $\mathrm{df1}$ & $\mathrm{df2}$ & Sig. \\
\hline .056 & 1 & 58 & .621 \\
\hline
\end{tabular}


From the results of the Levene test using the SPSS 22 program, it is known that for the homogeneity test with the Levene test, the value of sig $>\alpha(0.621>0.05)$ so that the null hypothesis is accepted, which means that all populations have the same/homogeneous variance. Thus the $\mathrm{N}$-gain data on the overall mathematical reasoning ability can be concluded to have the same or homogeneous variance.

Based on the normality and homogeneity test above, it can be concluded that the N-gain data of mathematical reasoning ability is normally distributed and has the same variance.

After testing the data analysis prerequisites, it was found that the $\mathrm{N}$-gain mathematical reasoning was normally distributed and had the same variance/homogeneity, then the analysis used next was parametric analysis using the t-test with the hypothesis:

$\mathrm{H} 0:^{\mu}=\mu_{y}$

Ha : $\mu_{x} \neq \mu_{y}$

Information:

$\mu_{x}$ : Improved mathematical reasoning skills taught by the guided discovery method assisted by Autograph.

$\mu_{y}$ : Improved mathematical reasoning skills taught by the guided discovery method without Autograph

The following shows the results of the N-gain t-test for the two sample classes using SPSS 22:

Tabel 6. Results of the t-test for Mathematical Reasoning Ability

Independent Samples Test

\begin{tabular}{|c|c|c|c|c|c|c|c|c|c|}
\hline & \multicolumn{4}{|c|}{$\begin{array}{l}\text { Levene's Test for Equality of } \\
\text { Variances }\end{array}$} & \multicolumn{5}{|c|}{ t-test for Equality of Means } \\
\hline & $\mathrm{F}$ & Sig. & $\mathrm{T}$ & df & $\begin{array}{c}\text { Sig. } \\
\text { (2-tailed) }\end{array}$ & $\begin{array}{c}\text { Mean } \\
\text { Difference }\end{array}$ & \begin{tabular}{|c|} 
Std. \\
Error \\
Differen \\
ce
\end{tabular} & $\begin{array}{r}9 \\
\text { Confic } \\
\text { Interval } \\
\text { Differ }\end{array}$ & $\begin{array}{l}5 \% \\
\text { lence } \\
\text { of the } \\
\text { ence }\end{array}$ \\
\hline & & & & & & & & $\begin{array}{l}\text { Low } \\
\text { er }\end{array}$ & $\begin{array}{l}\text { Upp } \\
\text { er }\end{array}$ \\
\hline $\begin{array}{cc} & \begin{array}{c}\text { Equal } \\
\text { variances }\end{array} \\
\text { assumed } \\
\text { Reasoning } \\
\text { Mathemati } \\
\text { cs Ability }\end{array} \begin{array}{c}\text { Equal } \\
\text { variances not } \\
\text { assumed }\end{array}$ & .056 & .724 & 2.174 & 57.708 & .003 & .13100 & $\begin{array}{l}.03686 \\
.03686\end{array}$ & .05721 & $\begin{array}{l}.20479 \\
.20480\end{array}$ \\
\hline
\end{tabular}

Based on the results of calculations in table 6 above, $\alpha=0.05$, the $t=2.174 \mathrm{t}$-table $=2.00$. $\mathrm{t}$-count $(2.174)>t$ table $(2.00)$ and the significance value $(0.003)<\alpha(0.05)$, so H0 is rejected. So that the increase in students' mathematical Reasoning Ability taught through the Autograph-assisted guided discovery learning method is higher than that taught through the guided discovery learning method without an autograph. Students with Autograph software and without Autograph software. The same 
Proceeding on International Conference of Science Management Art Research Technology (IC-SMART),

Vol. 1 (1), 71-77

Improving Mathematical Reasoning Ability Through Guided Discovery Methods Assisted By Autograph Software

Ismail Hanif Batubara, Marah Doly Nasution

opinion is also explained by (Ekaningsih, 2012), who explains that learning with the Autographassisted metacognitive approach can improve mathematical understanding and reasoning skills that are better than conventional/ordinary learning.

\section{CONCLUSION AND FURTHER RESEARCH}

The conclusion of this study is that the increase in the mathematical reasoning ability of the first group (GDL + Autograph) was higher than the second group (GDL without Autograph), in line with some of the research findings mentioned above. To improve students' mathematical reasoning abilities, educators can use the guided discovery method as an alternative. Then educators are expected to add insight into other learning theories and can apply them in learning mathematics in particular. In every lesson, the educator has to make learning that gives the learner opportunity to exact their opinions in their own way so that learning mathematics grows into courageous, confident, and creative. Educators can use Autograph software as a fun learning medium and also can use other software for further research.

\section{REFERENCES}

Shadiq, F. 2009. Junior High School Mathematics Learning Models Yogyakarta: Ministry of National Education's P4TK Mathematics.

Batubara, IH. 2017. Improving Mathematical Critical Thinking Ability Through Problem Based Learning Assisted by Autograph and Geogebra at SMA Freemethodist Medan. University of Muhammadiyah Sumatera Utara. V(6). 97-104. Retrieved from http://jurnal.umsu.ac.id/index.php/kumpulandosen/article/view/1368

Batubara, IH. 208. Peningkatan Kemampuan Pemahaman Konsep Melalui Metode Penemuan Terbimbing Melalui Software Autograph Pada Mata Kuliah Kalkulus Peubah Banyak.V(1), 5158, https://jurnal.uisu.ac.id/index.php/mesuisu/article/view/869

Rusefendi, E.T. 1993. Basic Statistics For Educational Research. Bandung: IKIP Bandung

Saragih, S. (2007). Developing Mathematical Thinking and Communication Skills for Junior High School Students Through a Realistic Mathematical Approach Bandung: Program Pascasarjana UPI Bandung.

Stanislaus, 2006. Pedoman Analisis Data dengan SPSS 16. Yogyakarta : Penerbit Graha Ilmu

Dwi Priyanto, 2009. Independent Learning with the SPSS Program. Jakarta Selatan : Penerbit Buku Kita

Sambas Ali, Dkk, 2009. Analysis of Correlation, Regression, and Anova Pathways in Research. Bandung : Penerbit CV Pustaka Setia

Sarwono, Jonathan. 2008. Penelitian Pendekatan Kuantitatif dan Kualitatif. Bandung: Lembaga Penelitian, Universitas Komputer Indonesia

Sugiyono. 2005. Statistics for research. Bandung : Penerbit CV Alfabeta Bandung

Ghozali, H. Imam. 2013. Multivariate Analysis Application with IBM SPSS 22 Program. Semarang: Badan Penerbit Universitas Diponegoro.

Alifah, A.U. 2018. Using of Autograph Software in Improving Students' Mathematical Reasoning Ability. Digital Library, UIN Sunan Gunung Djati, Bandung

Ekaningsih, B. 2012. Improving High School Students' Mathematical Understanding and Reasoning Ability through Autograph-assisted Metacognitive Approach.. Thesis. Indonesia University of Education.

Sriwahyuni, 2020. The Development Teaching Materials Subject Class Calculus of Many Variable Based on Discovery Learning Model at Education Faculty University of Muhammadiyah 
Proceeding on International Conference of Science Management Art Research Technology (IC-SMART), Vol. 1 (1), 71-77

Improving Mathematical Reasoning Ability Through Guided Discovery Methods Assisted By Autograph Software Ismail Hanif Batubara, Marah Doly Nasution

$\begin{array}{lllll}\text { Sumatera } & \text { Utara, } & \mathrm{V}(2), & 2 . & \text { Retrieved }\end{array}$ https://ojs.unimal.ac.id/index.php/ijevs/article/view/2137

Dachi, SW. 2020. The Development of Learning Model Through Problem Based Instruction on Student's Motivation Improvement In Mathematics Education, $\mathrm{V}(2), 2$, https://ojs.unimal.ac.id/index.php/ijevs/article/view/2284 